\title{
PARTICLE DISEASE. A COMPREHENSIVE THEORY OF PERIPROSTHETIC OSTEOLYSIS: A REVIEW
}

\author{
Jiří Gallo ${ }^{a^{*}}$, Petr Kamínek ${ }^{a}$, Vlastislava Ticháb, Petra Řihákováb, Rudolf Ditmar ${ }^{\mathrm{a}}$ \\ a Department of Orthopaedic Surgery, Palacký University Faculty of Medicine, 77515 Olomouc, Czech Republic \\ b Department of Pathology, Palacký University Faculty of Medicine, 77515 Olomouc, Czech Republic
}

Received: September 15, 2002

Key words: Arthroplasty / Complications / Pathogenesis / Periprosthetic osteolysis / Particle disease

Aseptic loosening and osteolysis are considered the main long-term problems of hip arthroplasty. Pathogenesis of periprosthetic osteolysis is multifactorial, and both the biological and mechanical factors seem to play an important role. Bearing surfaces continuously generate excessive amounts of micron and submicron particles provoking an adverse inflammatory response of periprosthetic connective tissues. In general, a key role has been attributed to macrophages. Cytokines, growth factors, $\mathrm{PGE}_{2}$, and enzymes are secreted with activated periprosthetic cells resulting in formation of osteolytic granulomas. The final osteolytic step is taken predominantly by osteoclasts which are getting ready for action mainly by an osteoprotegerin ligand (RANKL) and TNFa. Rankl is expressed by activated macrophages, osteoblasts, and lymphocytes. In parallel, a repetitive hydraulic effect of the joint fluid is manifested on the susceptible bone.

\section{INTRODUCTION}

Numerous studies illustrate clinical success of total hip arthroplasty. It is estimated that almost 1 million of total hip replacements are implanted world-wide annually. ${ }^{3}$ Surgery is considered as routine with a minimal rate of early complications offering a dramatic pain relief and improvement of the function. However, it remains only a time-limited solution for the damaged hip joint, since up to $30 \%$ of the patients can be revised within 10-14 years of the initial surgery. ${ }^{4}$

In the past several years, we have been facing an increasing number of hip arthroplasty revisions (Table 1). According to a report recently published by the Finnish arthroplasty register ${ }^{43}$ a 10 -year survival rate was observed in $72 \%$ and $90 \%$ of the patients younger than 55 years and above 70 years of age, respectively. Consequently, subsequent revisions have to be taken into account in younger patients. Aseptic loosening has been recognized as a main reason for revisions.

Osteolysis is almost always associated with aseptic loosening, but it could be seen with stable implants too (Fig. 1). It can be ascribed to an enhanced bone resorption closely related to endoprosthesis functioning. Santavirta et al. ${ }^{46}$ defined aggressive periprosthetic osteolysis as the local, progressive, tumor-like aseptic bone resorption which can be easily distinguished from the conventional linear form.

A bone is an extremely dynamic tissue, and the remodelling process is closely controlled at both the local and systemic levels (the genome, hormones, growth factors, cytokines, loading patterns, etc.). There are tight couplings between activities of osteoblasts and osteoclasts and matrix deposition and mineralization. In addition, the actual status of the prosthetic bone bed is influenced by the implant variables (material, design, mode of fixation, surface parameters, etc.). ${ }^{2}$ Inherent and/or acquired abnormalities can disturb the balance of the above-mentioned coupling mechanisms and shift them to the excessive bone resorption. Periprosthetic osteolysis belongs to acquired, local excessive bone resorption provoked by prosthesis functioning, but this process is also influenced by inborn factors.

Harris et al. ${ }^{10}$ reported aggressive osteolysis around an unstable cemented stem in 1976, whilst Jasty et al. ${ }^{21}$ observed osteolysis around a stable cemented one. Other authors described several cases with osteolysis around stable cementless implants..$^{32,33}$

Nevertheless, osteolysis is not the only reason for the periprosthetic bone loss that may be due to other factors, namely the so-called stress shielding and agerelated changes.

The research focused on recognizing the natural history of periprosthetic osteolysis is very important, particularly in view of seeking effective preventive measures. Several theories have been suggested to explain the pathogenesis of aseptic periprosthetic osteolysis. They can be simply divided into biological, physical or biophysical according to their scientific roots.

The aim of the present article is to review the "particle disease", ${ }^{11}$ a prominent biological theory of periprosthetic osteolysis and aseptic loosening. In parallel, the 


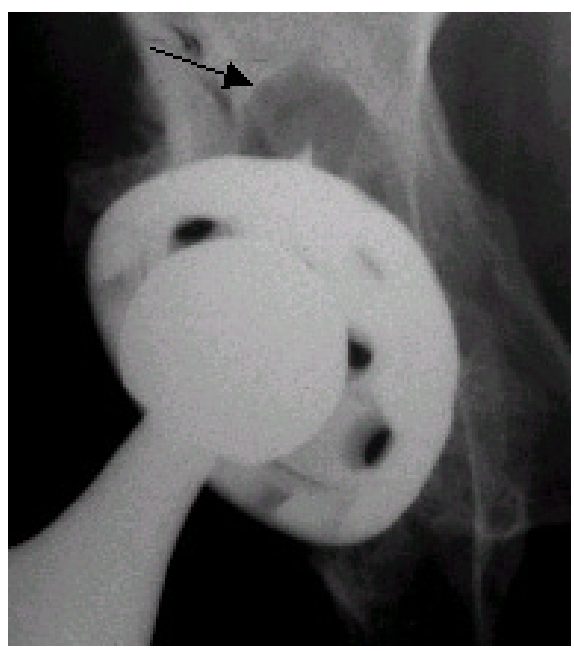

Fig. 1. Retroacetabular osteolysis (arrow) 4 years after primary surgery.

authors' intention is to show the extensive diffusion of fundamental research through the "conventional" orthopaedics.

\section{GENERATION OF PROSTHETIC PARTICLES}

A bone is a delicate tissue requiring some vital prerequisites for its fitness, but not the prosthetic detritus. It is a well-known fact that any hip prosthesis generates biologically active particles. Cementless modular implants seem to generate much more particles than cemented ones. There is a clinically evident association between the wear rate and the incidence of periprosthetic osteolysis..$^{41,50}$

The wear between the primary bearing surfaces is considered the most important source of prosthetic particles (i.e. microabrasions, microadhesions) ${ }^{47}$ These micro-separations of the surface material are inevitable for artificial hip and knee joints regardless of a prosthetic design or material characteristics. The wear rates among individual bearers are different in dependence upon implant types, surgical techniques and patient-related factors. Schmalzried et al. ${ }^{48}$ strongly argued the wear was a function of the amount and type of use of the prosthesis, not the time in situ. McKellop et al. ${ }^{36}$ estimated that a traditional metal-on-polyethylene joint pair (a polyethylene cup-metallic ball) generated several hundreds of thousands polyethylene particles during each gait cycle. More than $90 \%$ of these particles are less than $1 \mu \mathrm{m}$ in diameter with a mean size of $0.5 \mu \mathrm{m} .{ }^{34}$

The knowledge on polyethylene disease made necessary to develop modern alternative bearing surfaces to eliminate excessive generation of wear debris. It was found out that completely hard pairing (metal-on-metal or ceramic-on ceramic) improved significantly the wear resistance of artificial joints. ${ }^{18}$ The same effect has been achieved by means of cross-linked polyethylene either under laboratory ${ }^{37}$ or in vivo conditions. ${ }^{59}$

\section{PARTICLE DETERMINANTS}

Particles of all biomaterials used up-to-date can provoke an adverse biological reaction of periprosthetic tissues involving the formation of osteolytic foreign body granulomas, inhibition of the bone formation and joint fluid production..$^{56}$ The bone resorption leads ultimately to implant loosening. The extension of the bone destruction depends on the number, size, shape and composition of the particles. Hence, the specific biological activity of the debris can be established as the activity per unit volume of the wear material. ${ }^{18,19}$

Today, the standard bearing surface is polyethylene, therefore it can be a starting point. Polyethylene particles of irregular shapes within the size ranges from 0.2 to $7 \mu \mathrm{m}$ are known to represent the most hazardous fraction. ${ }^{18}$ Although Kadoya et al. ${ }^{23}$ set up a threshold for polyethylene osteolysis (i.e. $1 \times 10^{10}$ particles/gram periprosthetic tissue), and others demonstrated that the osteolytic effect was influenced by the size and concentration of the polyethylene particles in vitro ${ }^{9}$ or in vivo, ${ }^{28}$ still some doubts remain about the rigorous relationship between quantitative parameters and biological reactivity. For example Xing et al. ${ }^{60}$ found that particle surface chemistry affected significantly cytokine and enzyme secretion of the activated macrophages.

A great effort is focused on the research of the relative bioreactivity of alternative materials. In 2002 Ingham et al. ${ }^{19}$ presented a study confirming that ceramic-on-ceramic articulation had a lower osteolytic potential contrary to a metal-on metal configuration. In addition, it should be emphasized that $\mathrm{Co}-\mathrm{Cr}$ particles are more toxic than ceramic ones. ${ }^{19}$

\section{PATHOGENESIS OF PARTICLE DISEASE}

Willert and Semlitsch ${ }^{57,58}$ and many others documented a foreign body reaction (Fig. 2) and permanent inflammation of periprosthetic tissues in conjunction with the occurrence of a huge number of particles. Sabokbar et al..$^{45}$ as well as other researchers validated the particle disease concept through the exact in vitro ${ }^{39}$ and in vivo experiments..$^{13}$

Particulate wear debris generated mechanically from prosthetic surfaces can alter the function of a variety of cell types within the periprosthetic space including macrophages, fibroblasts, osteoblasts and osteoclasts by means of phagocytosis or surface activation. ${ }^{18,39,55}$ At present, monocyte/macrophages are believed to play a key role in the whole process. Mononuclear phagocyte cells attempt to eliminate large amounts of foreign particles in the joint space by means of phylogenetically proof phagocytosis. ${ }^{18}$ Small particles are easily phagocytosed, but they are unable to be digested. The inability to degrade the engulfed particles leads to the increased but vain production of numerous mediators and cytokines by stimulated macrophages. The result of this "combat" against particles is excessive accumulation 


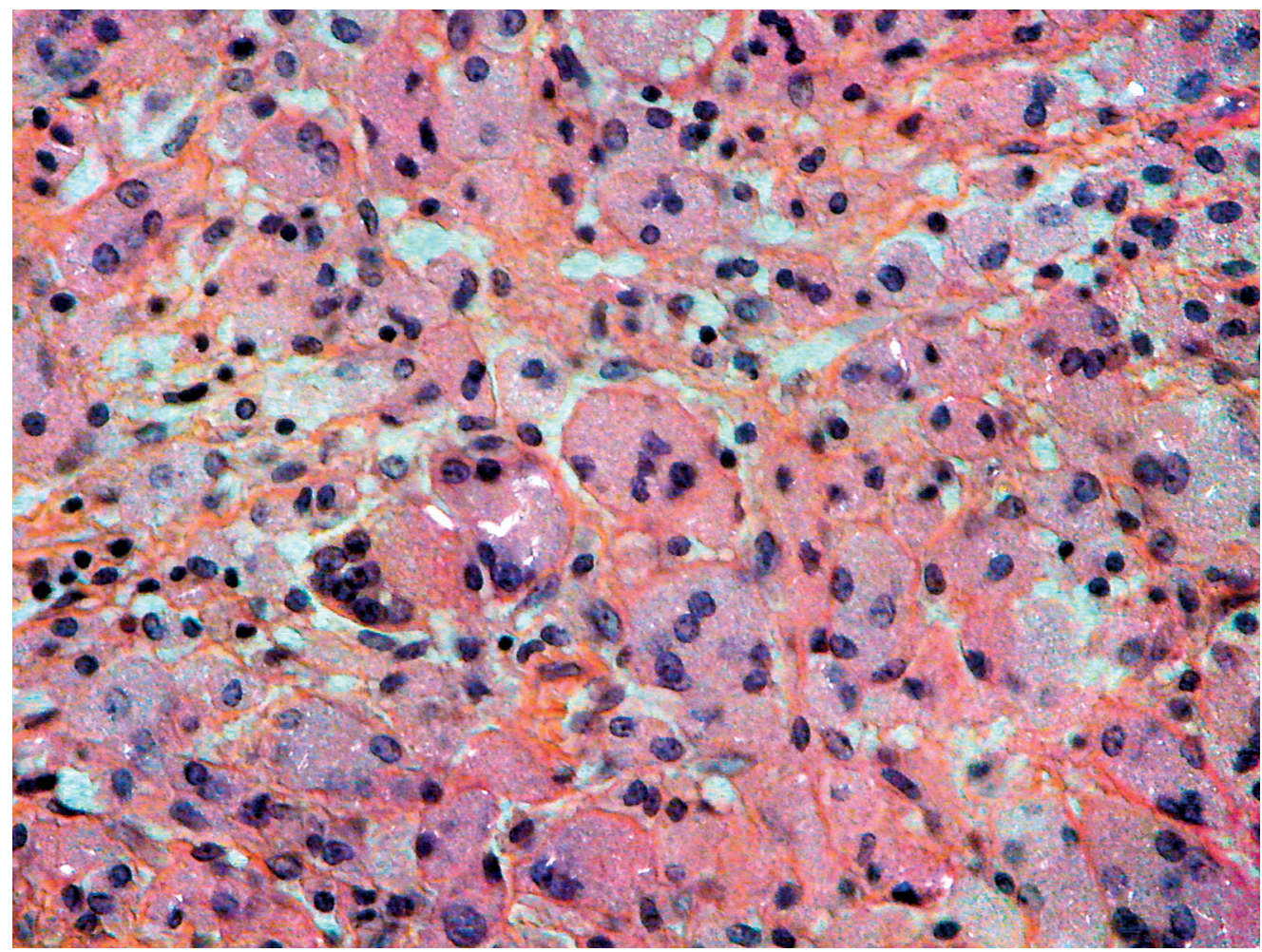

Fig. 2. A pseudocapsula with histiocytic infiltration. Wear particles are engulfed in cytoplasm of mononuclear histiocytes and in the interstitium. Larger particles are visible mostly in histiocytic giant cells. Polarized light. HE $\times 20$.

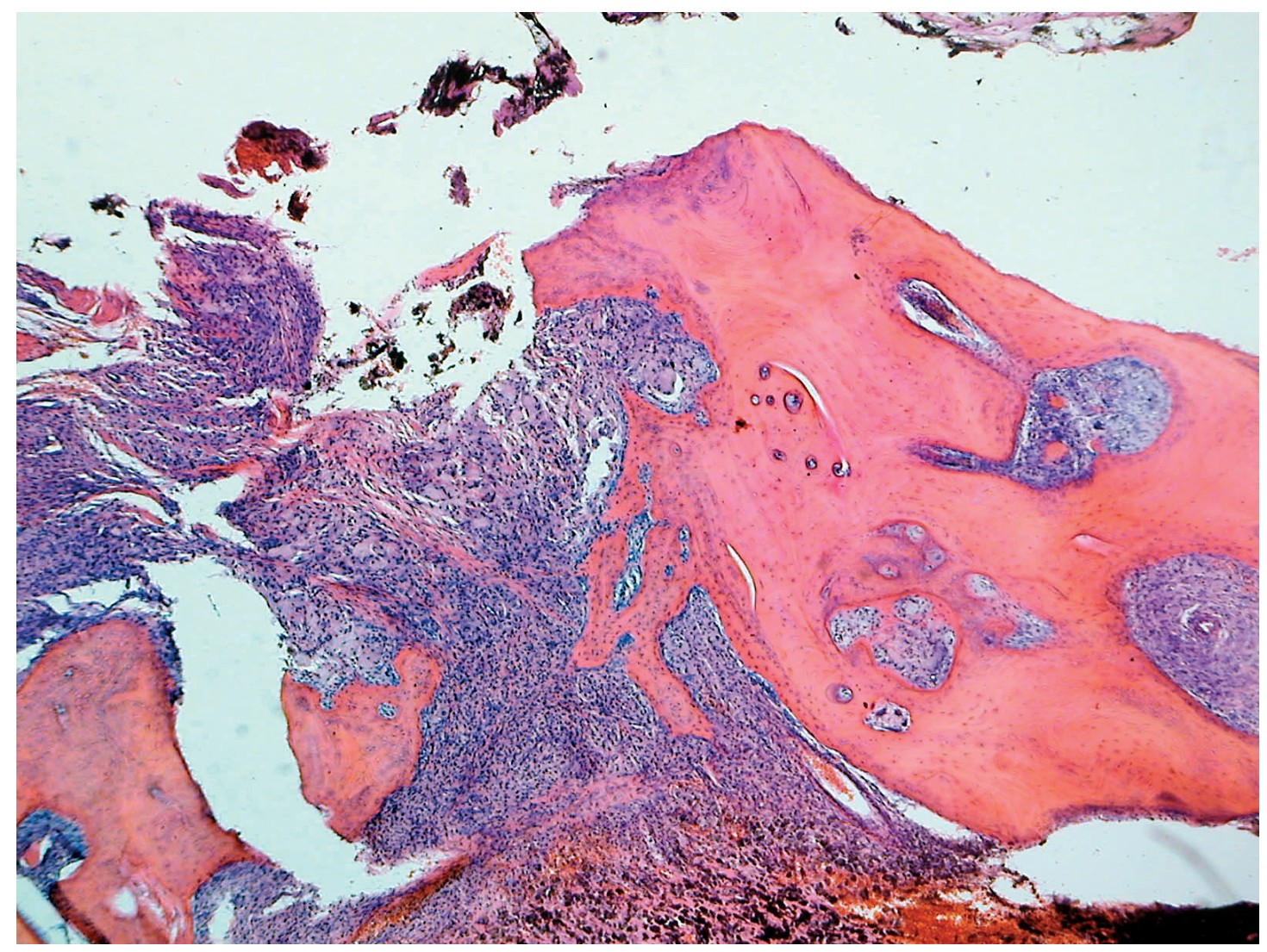

Fig. 3. A bone tissue retrieved during revision of a cementless prosthesis with hydroxyapatite coating. Histiocytic infiltrates are in the intimate contact with the bone trabeculae surface. HE $\times 40$. 

of bone-resorbing factors and osteolysis, ultimately (Fig. 3). The induction of macrophage apoptosis could be a desirable solution to this situation due to the elimination of the inflammatory reaction power. Petit et al. ${ }^{42}$ found the induction of macrophage apoptosis to be more insufficient with polyethylene particles as compared to ceramic ones. In general, the programme for cell death seems to be altered in the chronic inflammatory environment.

Through autocrine and paracrine signalling mechanisms,${ }^{55}$ the cells activated by particles release $\mathrm{PGE}_{2}{ }^{7}$ cytokines and growth factors (i.e. TNF- $\alpha$, IL-1B, IL-3, IL-6, M-CSF, GM-CSF, PDGF), ${ }^{40}$ chemokines (C-C chemokines, $\left.{ }^{38} \mathrm{MCP}-1^{54}\right)$, nitric oxide, ${ }^{15}$ metalloproteinases, ${ }^{51,53}$ and other factors. Among these cytokines, a TNF$\alpha$ signaling pathway seems to play a key role in the process of periprosthetic osteolysis development since it stimulates osteoclast formation, differentiation and activity. ${ }^{16,17}$ This may be through the mechanisms that are dependent and/or independent of the osteoclast differentiation factor (ODF, OPGL) ${ }^{26}$ Childs et al. ${ }^{17}$ really revealed that etanercept (soluble inhibitor of TNF$\alpha$ ) could inhibit osteoclastic bone resorption induced by the wear particles. The two final proteins controlling recruitment of the functional osteoclasts are a receptor activator of nuclear factor kappa $\beta$-ligand (RANKL, ODF, OPGL), and its antagonist osteoprotegerin (OPG, OCIF). ${ }^{6}$ RANKL stimulates the maturation of osteoclast progenitors by signalling through its membrane receptor RANK. RANK signalling seems to be inevitable for osteoclast differentiation, activation and survival. ${ }^{14}$ Osteoprotegerin is a TNF receptor-like molecule which inhibits osteoclast maturation and activity by blocking the binding of RANKL to the RANK on the osteoclast progenitor cells. ${ }^{49}$ RANKL is secreted by activated macrophages, osteoblasts, lymphocytes and other stromal cells. ${ }^{12,27}$ Kim et al. ${ }^{25}$ demonstrated that osteoprotegerin levels in the failed THA joint fluid were significantly lower compared to the control osteoarthritis group. Similarly, Goater et al. ${ }^{6}$ confirmed that osteoclastogenesis was completely suppressed by osteoprotegerin.

The bone resorption is attained by both osteoclasts and activated macrophages. Because macrophages represent a dominant cell type at the bone-osteolysis interface, some believe they are capable of direct bone resorption..$^{23,24}$ According to this concept, the osteoclasts execute rapid, extensive bone resorption, whereas the macrophages are engaged mainly in low-grade surface or high-grade lacunar osteolysis. ${ }^{44}$ Sabokbar et al. ${ }^{45}$ showed arthroplasty derived macrophages could differentiate into multinucleated osteoclastic bone resorbing cells.

Little is known about the role of osteocytes in the process of osteolysis. It has been demonstrated that in vitro polyethylene particles can increase the $\mathrm{PGE}_{2}$ and nitric oxide production of osteocyte-like cells. ${ }^{31}$

The poor periprosthetic bone quality may further contribute to the development of periprosthetic osteo- lysis. It was found that periprosthetic bone remodelling was more accelerated in association with an increasing particle-induced adverse host reaction resulting in fragile immature bone formation. ${ }^{52}$ Osteoblasts are mainly responsible for the mechanisms of bone formation. Paradoxically, they are able to phagocyte the prosthetic particles as shown eg. by the Chicago research group. ${ }^{54}$ The particle-osteoblast interaction results at least in the suppression of type I collagen synthesis and increased release of IL-6 and PGE 2 by activated osteoblasts. ${ }^{31,54,55}$ In addition, metallic particles affect osteoblast proliferation and viability, the most toxic being $\mathrm{Mn}, \mathrm{V}, \mathrm{Fe}$, $\mathrm{Cu}, \mathrm{Ni}, \mathrm{Co}{ }^{54} \mathrm{Bi}$ et al. ${ }^{1}$ believe that the stimulation of osteoclast differentiation and activity is quantitatively more important for the development of osteolysis contrary to the inhibition or distortion of the bone formation.

It is believed that the primary reaction to the prosthetic debris is a non-specific foreign body reaction, but at least in some patients a specific immune system may be involved in the process of osteolysis and aseptic loosening. Some investigators suggested a participation of T-cell mediated type IV hypersensitivity., ${ }^{5,29}$ Lymphocytes activation requires a specific antigenic stimulus in conjunction with the "costimulatory" signal presented by antigen-presenting cells (eg. dendritic cells or macrophages). One has to keep in mind that the cytokine milieu during T-cell activation is also important. A possible antigenic stimulus could be either a particle-protein complex $^{61}$ or endotoxin adsorbed on the prosthetic particles. Bi et al. ${ }^{1}$ found adherent endotoxin to be required for a titanium particle-induced osteolysis in their experiment. According to the "extended self, nonself theory" the professional antigen-presenting cells have to interact with some microbial components to elicit an immune response. ${ }^{20}$ The other authors failed to show any active role of lymphocytes in the periprosthetic tissues. 22,30 The controversies could be alleviated by better understanding of the immune system. For example, according to the slightly modified "danger theory" the professional antigen-presenting cells are also under certain circumstances activated by endogenous substances released by damaged bone tissues (eg. heatshock proteins). ${ }^{35}$

\section{CONCLUSIONS}

The principle of periprosthetic osteolysis is based on the permanent interference of a huge number of small prosthetic particles with periprosthetic tissue cells. Phagocytosis of wear particles does not seem necessary for osteolytic cascade induction. The key efferent structures are probably both the activated macrophages and osteoclasts. A repetitive action of the joint fluid and mechanical stresses help destroy the periprosthetic bone bed in conjunction with particle disease. 
Table 1. Causes and rates of aseptic revisions of total hip arthroplasty performed at the Orthopaedic Clinic in Olomouc between 1998 and 2001

\begin{tabular}{|l|c|c|c|c|}
\hline & $\mathbf{1 9 9 8}$ & $\mathbf{1 9 9 9}$ & $\mathbf{2 0 0 0}$ & $\mathbf{2 0 0 1}$ \\
\hline Aseptic loosening & 46 & 37 & 39 & 37 \\
\hline Osteolysis around stable components & 0 & 4 & 16 & 33 \\
\hline Periprosthetic fracture of the femur & 3 & 2 & 6 & 7 \\
\hline Dislocations & 2 & 5 & 8 & 9 \\
\hline Other reasons & 1 & 1 & 3 & 8 \\
\hline \hline Total & $\mathbf{5 2}$ & $\mathbf{4 9}$ & $\mathbf{7 2}$ & $\mathbf{9 4}$ \\
\hline
\end{tabular}

A List of Abbreviations Used:

$\begin{array}{ll}\text { TNF- } \alpha & \text { Tumor necrosis factor-alpha } \\ \text { IL-1ß, IL-3, IL-6, } & \text { Interleukins 1-beta, 3, } 6 \\ \text { M-CSF } & \text { Macrophage colony stimulating factor } \\ \text { GM-CSF } & \text { Granulocyte macrophage colony stimulating factor } \\ \text { PDGF } & \text { Platelet-derived growth factor } \\ \text { PGE } & \text { Prostaglandin E2 } \\ \text { C-C chemokines } & \text { Conserved - Cysteines chemokines } \\ \text { MCP-1 } & \text { Monocyte chemoattractant protein-1 } \\ \text { OPGL } & \text { Osteoprotegerin ligand } \\ \text { OCIF } & \text { Osteoclastogenesis inhibitory factor }\end{array}$

\section{ACKNOWLEDGMENTS}

The authors wish to thank Ms. J. Potomková for the revision of the English manuscript.

\section{REFERENCES}

1. Bi Y, Seabold JM, Kaar SG, Ragab AA, Goldberg VM, Anderson JM, Greenfield EM (2001) Adherent endotoxin on orthopedic wear particles stimulates cytokine production and osteoclast differentiation. J. Bone Miner. Res. 16, 2082-2091.

2. Buckwalter JA, Glimcher MJ, Cooper RR, Recker R (1995) Bone biology. Part II: Formation, form, modeling, remodeling, and regulation of cell function. J. Bone Jt Surg. 77-A, 1276-1289.

3. Čech O (2002) The revision hip arthroplasty. The causes, classification and therapeutic rules. Presented at the 6th national symposium of ČSOT, Prague, 16th-18th May 2002.

4. Duffy GP, Berry DJ, Rowland C, Cabanela ME (2001) Primary uncemented total hip arthroplasty in patients $<40$ years old. 10 to 14 -year results using first-generation proximally-coated implants. J. Arthroplasty 16, Suppl. 1, 140-144.

5. Evans EM (1974) Metal sensitivity as a cause of bone necrosis and loosening of the prosthesis in total joint replacement. J. Bone Jt Surg. 56-B, 626-642.

6. Goater JJ, O'Keefe RJ, Rosier RN, Puzas JE, Schwartz EM (2002) Efficacy of ex vivo OPG gene therapy in preventing wear debris induced osteolysis. J. Orthop. Res. 20, 169-173.

7. Goldring SR, Schiller AL, Roelke M, Rourke CM, O'Neil DA, Harris WH (1983) The synovial-like membrane at the bone-cement interface in loose total hip replacements and its proposed role in bone lysis. J. Bone Jt Surg. 65-A, 575-584.

8. Goodman SB (1996) Does the immune system play a role in loosening and osteolysis of total joint replacements? J. Long-term Eff. Med. Impl. 6, 91-101.

9. Green TR, Fisher J, Matthews JB, Stone MH, Ingham E (2000) Effect of size and dose on bone resorption activity of macrophages by in vitro clinically relevant ultra high molecular weight polyethylene particles. J. Biomed. Mater. Res. 53(5), 490-7.
10. Harris WH, Schiller A, Scholler JM, Frieberg RA, Scott R (1976) Extensive localised bone resorption in the femur following total hip replacement. J. Bone Jt Surg. 58-A, 612-618.

11. Harris WH (1994) Osteolysis and particle disease in hip replacement. A review. Acta Orthop. Scand. 65, 113-123.

12. Haynes DR, Crotti TN, Potter AE, Loric M, Atkins GJ, Howie DW, Findlay DM (2001) The osteoclastogenetic molecules RANKL and RANK are associated with periprosthetic osteolysis. J. Bone Jt Surg. 83-B, 902-911.

13. Howie DW, Vernon-Roberts B, Oakeshott R, Manthey B (1988) A rat model of resorption of bone at the cement-bone interface in the presence of polyethylene wear particles. J. Bone Jt Surg. 70-A, 257-263.

14. Hsu H, Lacey DL, Dunstan CR, Solovyev I, Colombero A, Timms E, Tan HL, Elliott G, Kelley MJ, Sarosi I, Wang L, Xia XZ, Elliott R, Chiu L, Black T, Scully S, Capparelli C, Morony S, Shimamoto G, Bass MB, Boyle WJ (1999) Tumor necrosis factor receptor family member RANK mediates osteoclast differentiation and activation induced by osteoprotegerin ligand. Proc. Nat. Acad. Science USA 96, 3540-3545.

15. Hukkanen M, Corbett SA, Platts LA, Konttinen YT, Hughes SP, Polak JM (1998) Nitric oxide in the local host reaction to total hip replacement. Clin. Orthop. 352, 53-65.

16. Childs LM, Goater JJ, O'Keefe RJ, Schwartz EM (2001) Effect of anti-tumor necrosis factor- $\alpha$ gene therapy on wear debris-induced osteolysis. J. Bone Jt Surg. 83-A, 1790-1797.

17. Childs LM, Goater JJ, O'Keefe RJ, Schwartz EM (2001) Efficacy of etanercept for wear debris-induced osteolysis. J. Bone Miner. Res. 16, 338-347.

18. Ingham E, Fisher J (2000) Biological reactions to wear debris in total joint replacement. Proc. Instn. Mech. Engrs., Part H, J. Engin. in Medicine 214, 21-37.

19. Ingham E (2002) Materials. Lecture in session 2: What materials should we use? Presented at the Wrightington International Arthroplasty Meeting, Manchester, 23rd-28th June 2002.

20. Janeway CA, Jr (1992) The immune system evolved to discriminate infectious nonself from noninfectious self. Immunol. Today $13,11-16$.

21. Jasty MJ, Floyd WE, III, Schiller AL, Goldring SR, Harris WH (1986) Localized osteolysis in stable, non-septic total hip replacement. J. Bone Jt Surg. 68-A, 912-919. 
22. Jiranek WA, Jasty M, Wang JT, Bragdon C, Wolfe H, Goldberg VM, Harris WH (1995) Tissue response to particulate polymethylmethacrylate in mice with various immune deficiencies. J. Bone Jt Surg. 77-A, 1650-1661.

23. Kadoya Y, Kobayashi A, Ohashi H (1998) Wear and osteolysis in total joint replacements. Acta Orthop. Scand. 69, Suppl. 278, $1-14$.

24. Kadoya Y, Revell PA, al-Safar N, Kobayashi A, Scott G, Freeman MA (1996) Bone formation and resorption in failed total joint arthroplasties: histomorphometric analysis with histochemical and immunohistochemical technique. J. Orthop. Res. 14, 473-482.

25. Kim KJ, Kotake S, Udagawa N, Ida H, Ishii M, Takei I, Kubo T, Takagi M (2001) Osteoprotegerin inhibits in vitro mouse osteoclast formation induced by joint fluid from failed total hip arthroplasty. J. Biomed. Mater. Res. 58(4), 393-400.

26. Kobayashi K, Takahashi N, Jimi E, Udagawa N, Takami M, Kotake S, Nakagawa N, Kinosaki M, Yamaguchi K, Shima N, Yasuda H, Morinaga T, Higashio K, Martin TJ, Suda T (2000) Tumor necrosis factor alpha stimulates osteoclast differentiation by a mechanism independent of the ODF/RANKL-RANK interaction. J. Exp. Med. 191, 275-286.

27. Kong YY, Feige U, Sarosi I, Bolon B, Tafuri A, Morony S, Capparelli C, Li J, Elliott R, McCabe S, Wong T, Campagnuolo G, Moran E, Bogoch ER, Van G, Nguyen LT, Ohashi PS, Lacey DL, Fish E, Boyle WJ, Penninger JM (1999) Activated T cells regulate bone loss and joint destruction in adjuvant arthritis through osteoprotegerin ligand. Nature 402, 304-309.

28. Kubo T, Sawada K, Hirakawa K, Shimizu C, Takamatsu Y (1999) Histiocyte reaction in rabbit femur to UHMWPE, metal, and ceramic particles in different sizes. J. Biomed. Mater. Res., 45, 363-369.

29. Lalor PA, Rewell PA, Gray AB, Wright S, Railton GT, Freeman MA (1991) Sensitivity to titanium. A cause of implant failure? J. Bone Jt Surg. 73-B, 25-28.

30. Li T-F, Santavirta S, Waris V, Lassus J, Lindroos L, Xu J-W, Virtanen I, Konttinen YT (2001) No lymphokines in T-cells around loosened hip prostheses. Acta Orthop Scand 72, 241-247.

31. Lohmann CH, Dean DD, Bonewald, LF, Schwartz Z, Boyan BD (2002) Nitric oxide and prostaglandin E2 production in response to ultra-high molecular weight polyethylene particles depends on osteoblast maturation state. J. Bone Jt Surg. 84-A, 411-419.

32. Maloney WH, Peters P, Engh CA, Chandler H (1993) Severe osteolysis of the pelvis in association with acetabular replacement without cement. J. Bone Jt Surg. 75-A, 1627-1635.

33. Maloney WJ, Jasty MJ, Harris WH, Galante, J. O., Callaghan, J. J. (1990) Endosteal erosion in association with stable uncemented femoral components. J. Bone Jt Surg. 72-A, 1025-1034.

34. Maloney WJ, Smith R, Schmalzried TP, Chiba J, Huene D, Rubash HE (1995) Isolation and characterization of debris in membranes around total joint prostheses. J. Bone Jt Surg. 77-A, 1301-1310.

35. Matzinger P (1998) An innate sense of danger. Semin. Immunol. $10,399-415$

36. McKellop HA, Campbell P, Park S-H, Schmalzried TP, Grigoris P, Amstutz HC, Sarmiento A (1995) The origin of submicron polyethylene wear debris in total hip arthroplasty. Clin. Orthop. 311, 3-20.

37. McKellop HA, Shen F-W, Lu B, Campbell P, Salovey R (1999) Development of an extremely wear-resistant ultra high molecular weight polyethylene for total hip replacements. J. Orthop. Res. 17(2), 157-167.

38. Nakashima Y, Sun D-H, Trindade MCD, Chun LE, Song Y, Goodman SB, Schurman DJ, Maloney WJ, Smith RL (1999) Induction of macrophage $\mathrm{C}-\mathrm{C}$ chemokine expression by titanium alloy and bone cement particles. J. Bone Jt Surg. 81-B, 155-162.

39. Nakashima Y, Sun D-H, Trindade MCD, Maloney WJ, Goodman SB, Schurman DJ, Smith RL (1999) Signaling pathways for tumor necrosis factor-alpha and IL-6 expression in human macrophages exposed to titanium-alloy particulate debris in vitro. J. Bone Jt Surg. 81-A, 603-615.
40. Neale SD, Athanasou NA (1999) Cytokine receptor profile of arthroplasty macrophages, foreign body giant cells and mature osteoclasts. Acta Orthop. Scand. 70, 452-458.

41. Oparaugo PC, Clarke IC, Malchau H, Herberts P (2001) Correlation of wear debris-induced osteolysis and revision with volumetric wear-rates of polyethylene. A survey of 8 reports in the literature. Acta Orthop. Scand. 72, 22-28.

42. Petit A, Catelas I, Antoniou J, Zukor DJ, Huk OL (2002) Differential apoptotic response of J774 macrophages to alumina and ultrahigh-molecular-weight polyethylene particles. J. Orthop. Res. 20, 9-15.

43. Puolakka TJS, Pajamäki KJJ, Halonen PJ, Pulkkinen PO, Paavolainen P, Nevalainen JK (2001) The Finnish arthroplasty register. Report of the hip register. Acta Orthop. Scand. 72, 433-441.

44. Quinn J, Joyner C, Triffit JT, Athanasou NA (1992) Polymethylmethacrylate-induced inflammatory macrophages resorb bone. J. Bone Jt Surg. 74-B, 652-658.

45. Sabokbar A, Fujikawa Y, Neale S, Murray DW, Athanasou NA (1997) Human arthroplasty derived macrophages differentiate into osteoclastic bone resorbing cells. Annals Rheum. Dis. 56, 414-420.

46. Santavirta S, Xu J-W, Hietanen J, Ceponis A, Sorsa T, Kontio R, Konttinen YT (1998) Activation of periprosthetic connective tissue in aseptic loosening of total hip replacements. Clin. Orthop. $352,16-24$.

47. Schmalzried TP, Callaghan JJ (1999) Wear in total hip and knee replacements. J. Bone Jt Surg. 81-A, 115-136.

48. Schmalzried TP, Shepherd EF, Dorey FJ, Jackson WO, dela Rosa M, Fa'vae F, McKellop HA, McClung CD, Martell J, Moreland JR, Amstutz HC (2000) Wear is a function of use, not time. The John Charnley Award. Clin. Orthop. 381, 36-46.

49. Simonet WS, Lacey DL, Dunstan CR, Kelley M, Chang MS, Luthy R, Nguyen HQ, Wooden S, Bennett L, Boone T, Shimamoto G, DeRose M, Elliott R, Colombero A, Tan HL, Trail G, Sullivan J, Davy E, Bucay N, Renshaw-Gegg L, Hughes TM, Hill D, Pattison W, Campbell P, Boyle WJ, et al. (1997) Osteoprotegerin: A novel secreted protein involved in the regulation of bone density. Cell 89, 309-319.

50. Sochart DH (1999) Relationship of acetabular wear to osteolysis and loosening in total hip arthroplasty. Clin. Orthop. 363, 135-150.

51. Takagi M, Konttinen YT, Santavirta S, Sorsa T, Eisen AZ, Nordsletten L, Suda A (1994) Extracellular matrix metalloproteinases around loose total hip prostheses. Acta Orthop. Scand. 65, 281-286.

52. Takagi M, Santavirta S, Ida H, Ishii M, Takei I, Niissalo S, Ogino T, Konttinen YT (2001) High-turnover periprosthetic bone remodeling and immature bone formation around loose cemented total hip joints. J. Bone Miner. Res. 16, 79-88.

53. Takei I, Takagi M, Santavirta S, Ida H, Ishii M, Ogino T, Ainola M, Konttinen YT (2000) Messenger ribonucleic acid expression of 16 matrix metalloproteinases in bone-implant interface tissues of loose artificial hip joints. J. Biomed. Mater. Res. 15, 52(4), 613-20.

54. Vermes C, Glant TT, Hallab NJ, Fritz EA, Roebuck KA, Jacobs JJ (2001) The potential role of the osteoblast in the development of periprosthetic osteolysis. Review of in vitro osteoblast responses to wear debris, corrosion products, and cytokines and growth factors. J. Arthroplasty 16, Suppl. 1, 95-100.

55. Vermes C, Chandrasekaran R, Jacobs JJ, Galante JO, Roebuck KA, Glant TT (2001) The effects of particulate wear debris, cytokines, and growth factors on the functions of MG-63 osteoblasts. J. Bone Jt Surg. 83-A, 201-211.

56. Willert H-G, Buchhorn GH (1999) The biology of the loosening of the hip implants. Europ. Instr. Course Lect. Vol. 4, 58-82.

57. Willert H-G, Semlitsch M (1977) Reactions of the articular capsule to wear products of artificial joint prostheses. J. Biomed. Mater. Res. 11, 157-164.

58. Willert H-G, Semlitsch M (1976) Tissue reactions to plastic and metallic wear products of joint endoprostheses. In Gschwend, N., Debrunner, H. U., eds. Total hip prostheses. Verlag Hans Huber, pp. 205-239. 
59. Wroblewski BM, Siney PD, Fleming PA (1999) Low-friction arthroplasty of the hip using alumina ceramic and cross-linked polyethylene. A ten-year follow-up report. J. Bone Jt Surg. 81-B, $54-55$.

60. Xing S, Santerre JP, Labow RS, Boynton EL (2002) Differential response to chemically altered polyethylene by activated mature human monocyte-derived macrophages. Biomaterials 23, 3595-3602.
61. Wooley PH, Fitzgerald Jr, RH, Song Z, Davis P, Whalen JD, Trumble S, Nasser S (1999) Proteins bound to polyethylene components in patients who have aseptic loosening after total joint arthroplasty. A preliminary report. J. Bone Jt Surg. 81-A, 616-623. 